\title{
3D data related to the publication: A new species of Palaeopython (Serpentes) and other extinct squamates from the Eocene of Dielsdorf (Zurich, Switzerland)
}

\author{
Georgalis Georgios L. ${ }^{1,2,3}$, Scheyer Torsten M. ${ }^{4 *}$ \\ ${ }^{1}$ Department of Ecology, Laboratory of Evolutionary Biology, Faculty of Natural Sciences, Comenius University in Bratislava, Mlynská dolina, 84215 \\ Bratislava, Slovakia \\ ${ }^{2}$ Department of Geosciences, University of Fribourg, Chemin du Musée 6, 1700 Fribourg, Switzerland \\ ${ }^{3}$ Department of Earth Sciences, University of Torino, Via Valperga Caluso 35, 10125 Turin, Italy \\ ${ }^{4}$ University of Zurich, Palaeontological Institute and Museum, Karl Schmid-Strasse 4, CH- 8006 Zurich, Switzerland. \\ ${ }^{*}$ Corresponding author: tscheyer@pim.uzh.ch
}

\section{Abstract}

The present 3D Dataset contains the 3D models analyzed in the following publication: Georgalis, G. L., and T. M. Scheyer. A new species of Palaeopython (Serpentes) and other extinct squamates from the Eocene of Dielsdorf (Zurich, Switzerland). Swiss Journal of Geosciences (in press). https://doi.org/10.1007/s00015-019-00341-6

Keywords: Eocene, Palaeopython, Palaeovaranus, Squamata, Switzerland

Submitted:2019-05-13, published online:2019-06-05. https://doi.org/10.18563/journal.m3.93

\begin{tabular}{|c|c|c|}
\hline Inv nr & Taxon & Description \\
\hline PIMUZA/III631-M3\#399 & $\begin{array}{c}\text { Palaeopython } \\
\text { helveticus }\end{array}$ & $\begin{array}{l}\text { Vertebra } \\
\text { (surface) }\end{array}$ \\
\hline PIMUZA/III631-M3\#403 & $\begin{array}{l}\text { Palaeopython } \\
\text { helveticus }\end{array}$ & $\begin{array}{l}\text { Vertebra } \\
(\mu \mathrm{CT} \text { data) }\end{array}$ \\
\hline PIMUZA/III634-M3\#400 & $\begin{array}{c}\text { Palaeopython } \\
\text { helveticus }\end{array}$ & $\begin{array}{l}\text { Vertebra } \\
\text { holotype } \\
\text { (surface) }\end{array}$ \\
\hline PIMUZA/III634-M3\#404 & $\begin{array}{l}\text { Palaeopython } \\
\text { helveticus }\end{array}$ & $\begin{array}{l}\text { Vertebra } \\
\text { holotype } \\
\text { ( } \mu \text { CT data) }\end{array}$ \\
\hline PIMUZA/III636-M3\#401 & $\begin{array}{c}\text { Palaeopython } \\
\text { helveticus }\end{array}$ & $\begin{array}{l}\text { Vertebra } \\
\text { (surface) }\end{array}$ \\
\hline PIMUZA/III636-M3\#406 & $\begin{array}{c}\text { Palaeopython } \\
\text { helveticus }\end{array}$ & $\begin{array}{l}\text { Vertebra } \\
(\mu \mathrm{CT} \text { data) }\end{array}$ \\
\hline PIMUZA/III234-M3\#402 & $\begin{array}{c}\text { Palaeovaranus } \\
\text { sp. }\end{array}$ & $\begin{array}{l}\text { Isolated } \\
\text { dentary } \\
\text { (surface) }\end{array}$ \\
\hline PIMUZA/III234-M3\#405 & $\begin{array}{c}\text { Palaeovaranus } \\
\text { sp. }\end{array}$ & $\begin{array}{c}\text { Isolated } \\
\text { dentary }(\mu \mathrm{CT} \\
\text { data) }\end{array}$ \\
\hline
\end{tabular}

Table 1. List of surface and $\mu \mathrm{CT}$ data included in this study. All specimen belong to the Palaeontological Institute and Museum of the University of Zurich.

\section{INTRODUCTION}

CT scanning was conducted in three different-sized snake vertebrae of Palaeopython helveticus sp. nov., including its holotype PIMUZ A/III 634, from Eocene fissure fills at Dielsdorf, near Zurich, Switzerland (e.g., Rosselet, 1991) in order to detect and evaluate ontogenetic variability in these fossils. In addition, a dentary of Palaeovaranus sp. was scanned to elucidate its internal histology and tooth implementation (Fig. 1 and Table $1)$.

\section{METHODS}

The bones (snake vertebrae; dentary) from Dielsdorf were scanned with a Nikon XTH 225 ST CT Scanner housed at the Anthropological Department of the University of Zurich. The microcomputed tomography scan of the vertebrae was taken with a voltage of $91 \mathrm{kV}$ and a current of $345 \mu \mathrm{A}$, yielding a voxel size of $0.03758 \mathrm{~mm}$, with no filter used. The dentary was scanned with a voltage of $162 \mathrm{kV}$, a current of $102 \mu \mathrm{A}$, yielding a voxel size of $0.01654 \mathrm{~mm}$, again with no filter used. Reconstruction of the digital stack for virtual 3D reconstruction was achieved using VG Studio Max 2.2. The 3D surface models are provided in .ply format and the datasets in DICOM format, and can therefore be opened with a wide range of freeware.

\section{ACKNOWLEDGEMENTS}

Grant sponsor: SYNTHESYS. Grant numbers: ES-TAF-5910 (MNCN), AT-TAF-5911 (NHMW), HU-TAF-6145 (HNHM), GB-TAF-6591 (NHMUK), all to GLG.

Grant sponsor: Swiss National Science Foundation. Grant number: 205321_16277 to TMS.

\section{BIBLIOGRAPHY}

Georgalis, G. L., and T. M. Scheyer. A new species of Palaeopython (Serpentes) and other extinct squamates from the Eocene of Dielsdorf (Zurich, Switzerland). Swiss Journal of Geosciences (in press). https://doi.org/10.1007/s00015-019-003416

Rosselet, C., 1991. Die Fauna der Spaltenfüllungen von Dielsdorf (Eozän, Kanton Zürich). Documenta naturae 64, 1-177. 

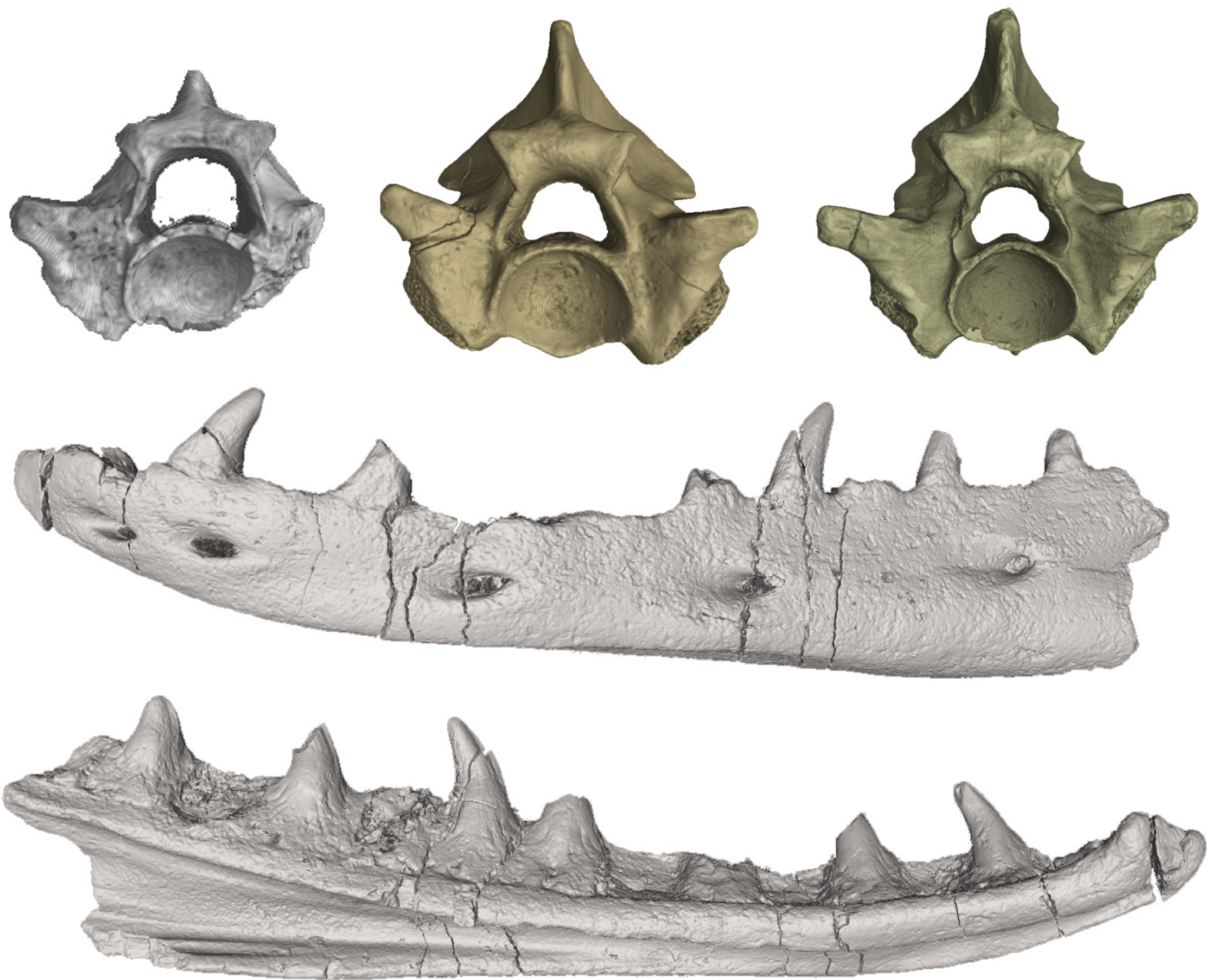

Figure 1. 3D models of the three snake vertebrae of Palaeopython helveticus sp. nov. (left to right: PIMUZ A/III 631, PIMUZ A/III 636, PIMUZA/III 634 (holotype); Palaeontological Institute and Museum of the University of Zurich) in anterior view and the Palaeovaranus dentary (PIMUZ A/III 234) in lateral and medial view. 